Supplement of SOIL, 2, 147-162, 2016

http://www.soil-journal.net/2/147/2016/

doi:10.5194/soil-2-147-2016-supplement

(C) Author(s) 2016. CC Attribution 3.0 License.

(c) (i)

Supplement of

\title{
Organic wastes from bioenergy and ecological sanitation as a soil fertility improver: a field experiment in a tropical Andosol
}

\section{A. Krause et al.}

Correspondence to: Ariane Krause (krause@ztg.tu-berlin.de)

The copyright of individual parts of the supplement might differ from the CC-BY 3.0 licence. 
Table S1. Provision of plot data for Fig. 2: untreated Andosol and soil treated with biogas slurry, compost, and CaSa-compost; measured using ceramic pressure plates.

\begin{tabular}{lrrr}
\hline & \multicolumn{1}{c}{$\mathrm{pF}$} & \multicolumn{1}{c}{$\theta$} & Error $(\theta)$ \\
\hline Andosol ceramic plate & 0 & 0,593 & 0,013 \\
& 1,8 & 0,357 & 0,014 \\
& 2,5 & 0,292 & 0,014 \\
& 3 & 0,262 & 0,007 \\
Biogas slurry & 4,2 & 0,228 & 0,022 \\
& 0 & 0,621 & 0,022 \\
& 1,8 & 0,355 & 0,028 \\
& 2,5 & 0,294 & 0,028 \\
& 3 & 0,268 & 0,025 \\
Compost & 4,2 & 0,221 & 0,021 \\
& 0 & 0,634 & 0,045 \\
& 1,8 & 0,344 & 0,028 \\
CaSa-compost & 2,5 & 0,286 & 0,025 \\
& 3 & 0,250 & 0,041 \\
& 4,2 & 0,227 & 0,022 \\
& 0 & 0,594 & 0,029 \\
& 1,8 & 0,353 & 0,021 \\
& 2,5 & 0,290 & 0,015 \\
& 3 & 0,265 & 0,015 \\
& 4,2 & 0,223 & 0,020 \\
\hline
\end{tabular}

Table S2: Fitted parameters of the PDI model of the untreated Andosol version of the unconstrained Mualemvan Genuchten (MvG) model, curve shown in Fig. 2.

\begin{tabular}{lrrrrrr}
\hline fitted Parameter & \multicolumn{1}{c}{ Unit } & \multicolumn{1}{c}{ Value } & \multicolumn{1}{c}{ Min } & Max & \multicolumn{1}{c}{$2.5 \%$} & \multicolumn{1}{c}{$97.5 \%$} \\
\hline alpha & $1 \mathrm{~cm}^{-1}$ & 0.0441 & 0.00001 & 0.5 & 0.0361 & 0.0538 \\
$\mathrm{n}$ & - & 3 & 1.01 & 15 & 2,622 & 4,622 \\
th_r & $\mathrm{cm}^{3} \mathrm{~cm}^{-3}$ & 0.358 & 0 & 0.4 & 0.352 & 0.364 \\
th_s & $\mathrm{cm}^{3} \mathrm{~cm}^{-3}$ & 0.556 & 0.1 & 1 & 0.55 & 0.562 \\
\hline
\end{tabular}

with $\mathrm{pF}$ (dry) set to 6.8 and a set to -1.5 
Table S3. Provision of plot data for Fig. 3: Total above-ground biomass production and marketable crop yields given as g per plot.

\begin{tabular}{|c|c|c|c|c|c|c|c|c|c|c|}
\hline \multicolumn{11}{|c|}{ Total above-ground biomass production $\left[\mathrm{g} \mathrm{plot}^{-1}\right]$} \\
\hline & \multicolumn{2}{|c|}{ Onion } & \multicolumn{2}{|c|}{ Carrot } & \multicolumn{2}{|c|}{ Cabbage } & \multicolumn{2}{|c|}{ Beans } & \multicolumn{2}{|c|}{ Maize } \\
\hline Control Andosol & 880 & $\mathrm{a}$ & 1312 & $\mathrm{a}$ & no & & 192 & $\mathrm{a}$ & 7177 & $\mathrm{a}$ \\
\hline Biogas slurry & 1211 & $a b$ & 2439 & $\mathrm{a}$ & 7417 & $\mathrm{~b}$ & 360 & $a b$ & 10028 & $\mathrm{a}$ \\
\hline Compost & 1679 & $\mathrm{~b}$ & 2991 & $\mathrm{a}$ & 8571 & $\mathrm{~b}$ & 518 & $\mathrm{~b}$ & 11086 & $a b$ \\
\hline CaSa-Compost & 1516 & $\mathrm{ab}$ & 2169 & $\mathrm{a}$ & 9390 & $\mathrm{~b}$ & 1244 & $\mathrm{c}$ & 15173 & $\mathrm{~b}$ \\
\hline \multicolumn{11}{|c|}{ Yields of food crops [g plot $\left.{ }^{-1}\right]$} \\
\hline & \multicolumn{2}{|c|}{$\begin{array}{l}\text { Onion bulb } \\
\text { (air-dried) }\end{array}$} & \multicolumn{2}{|c|}{$\begin{array}{l}\text { Carrot } \\
\text { (fresh) }\end{array}$} & \multicolumn{2}{|c|}{$\begin{array}{l}\text { Head of Cabbage } \\
\text { (fresh) }\end{array}$} & \multicolumn{2}{|c|}{ Beans } & \multicolumn{2}{|c|}{$\begin{array}{l}\text { Maize grains } \\
\text { (air-dried) }\end{array}$} \\
\hline Control Andosol & 444 & $\mathrm{a}$ & 918 & $\mathrm{a}$ & & & n.a. & & 497 & $\mathrm{a}$ \\
\hline Biogas slurry & 691 & $\mathrm{ab}$ & 1707 & $\mathrm{a}$ & 4320 & $\mathrm{~b}$ & n.a. & & 1181 & $a b$ \\
\hline Compost & 1056 & $\mathrm{~b}$ & 2093 & $\mathrm{a}$ & 4950 & $\mathrm{~b}$ & n.a. & & 1431 & $\mathrm{bc}$ \\
\hline CaSa-Compost & 1088 & $\mathrm{~b}$ & 1518 & $\mathrm{a}$ & 6101 & $\mathrm{~b}$ & n.a. & & 1973 & $\mathrm{c}$ \\
\hline
\end{tabular}

Different letters reflect means differing significantly from one another (HSD, Tukey test, $\alpha=0.05 ; n=4$ for the untreated control plots and $n=5$ for the amended plots). n.a. not available 
Table S4. Provision of plot data for Fig. 4: Total nutrient concentration in DM, total nutrient uptake, and air-dry grain yield. The response levels (relative nutrient concentration, relative nutrient uptake, and relative biomass) are given relative to the control treatment's performance, which was set $100 \%$.

\begin{tabular}{|c|c|c|c|c|c|c|c|c|c|c|c|c|}
\hline & \multicolumn{6}{|c|}{ Total nutrient concentration in dry maize grains } & \multicolumn{6}{|c|}{ Relative nutrient concentration in dry maize grains } \\
\hline Control Andosol & 15,9 & 2,3 & 4,4 & 0,1 & 1,0 & 22,1 & 100,0 & 100,0 & 100,0 & 100,0 & 100,0 & 100,0 \\
\hline Biogas slurry & 16,5 & 2,6 & 4,0 & 0,1 & 1,0 & 18,0 & 103,6 & 113,5 & 91,5 & 74,8 & 97,9 & 81,4 \\
\hline CaSa-Compost & 16,8 & 3,0 & 3,9 & 0,1 & 1,1 & 18,2 & 105,8 & 128,8 & 88,2 & 75,8 & 109,4 & 82,3 \\
\hline & \multicolumn{6}{|c|}{ Total nutrient uptake in dry maize grains } & \multicolumn{6}{|c|}{ Relative nutrient uptake in dry maize grains } \\
\hline Control Andosol & 0,33 & 0,05 & 0,09 & 0,00 & 0,02 & 0,46 & 100,0 & 100,0 & 100,0 & 100,0 & 100,0 & 100,0 \\
\hline Biogas slurry & 0,79 & 0,13 & 0,19 & 0,00 & 0,05 & 0,87 & 240,8 & 263,6 & 212,6 & 173,9 & 227,5 & 189,1 \\
\hline Compost & 1,13 & 0,18 & 0,27 & 0,01 & 0,07 & 1,38 & 343,8 & 379,4 & 290,3 & 288,0 & 347,2 & 301,5 \\
\hline CaSa-Compost & 1,51 & 0,27 & 0,35 & 0,01 & 0,10 & 1,63 & 456,1 & 555,2 & 380,2 & 326,5 & 471,4 & 354,7 \\
\hline
\end{tabular}

\begin{tabular}{lll}
\hline & $\begin{array}{l}\text { Total biomass } \\
\text { air-dry grain yield } \\
\text { g plant }^{-1}\end{array}$ & $\begin{array}{l}\text { Relative biomass } \\
\text { air-dry grain yield } \\
\%\end{array}$ \\
\cline { 2 - 3 } Control Andosol & 33,0 & 100 \\
Biogas slurry & 68,0 & 206 \\
Compost & 89,6 & 271 \\
CaSa-Compost & 119,1 & 361 \\
\hline Different letters reflect means differing significantly from one another (HSD, Tukey test, $\alpha=0.05 ; \mathrm{n}=3)$.
\end{tabular}




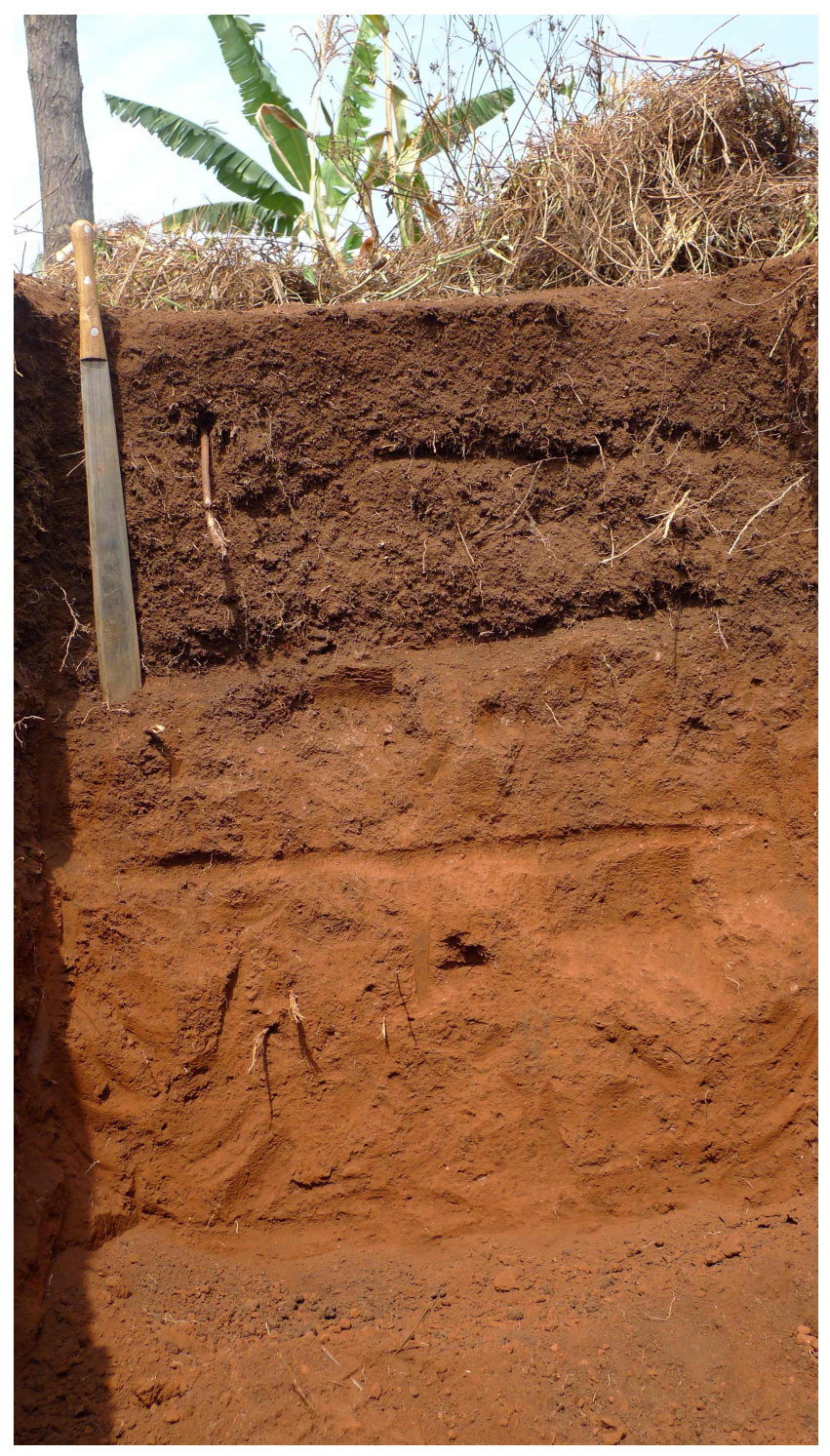

Fig. S1. The soil profile. The blade of the machete was $\sim 0.3 \mathrm{~m}$ The photograph was taken by A. Krause on February 2nd, 2014. 


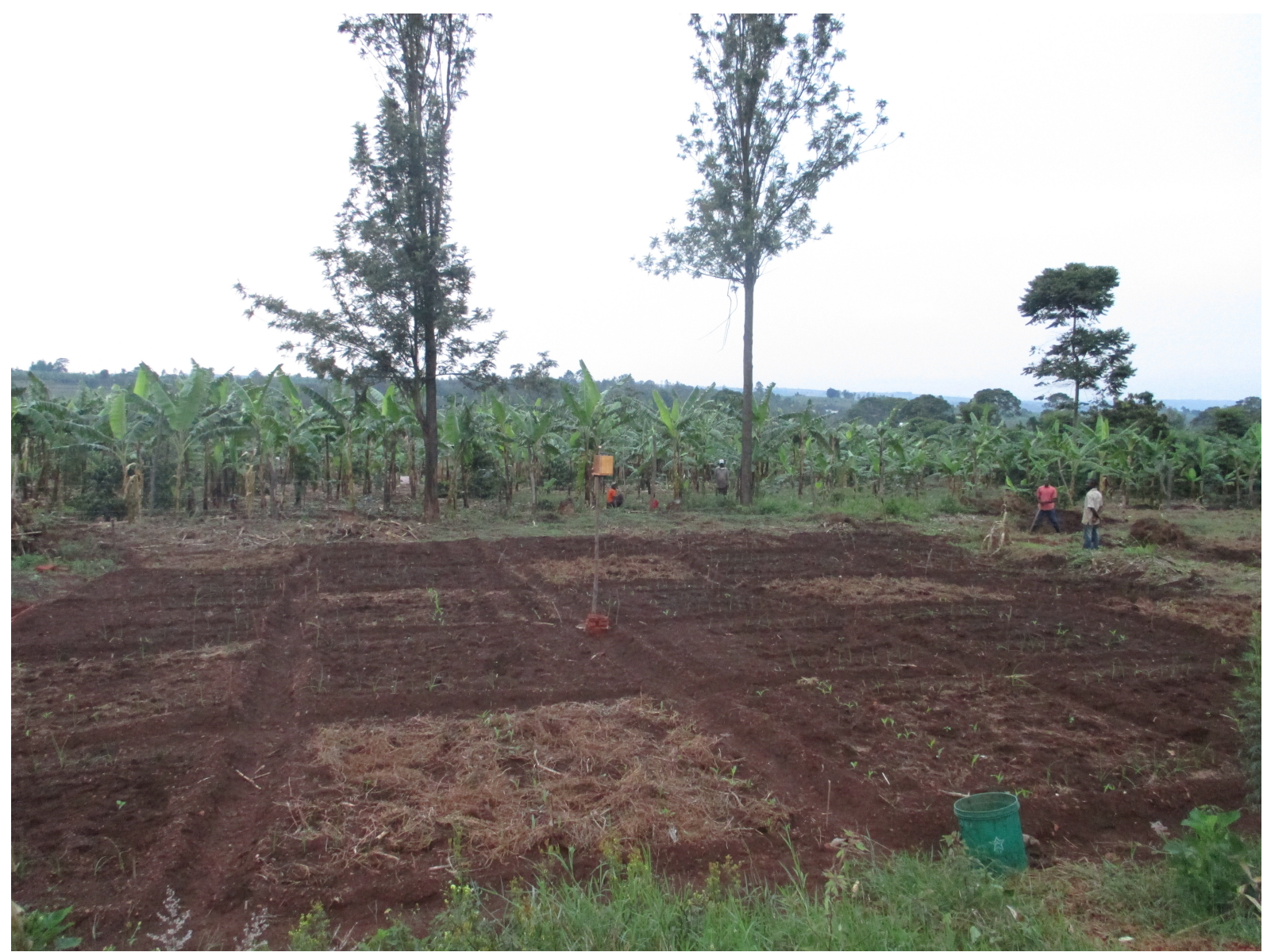

Fig. S2. The experimental site - 10 days after initiating the experiment with sowing of maize. The photograph was taken by A. Krause on March 14th, 2014. 


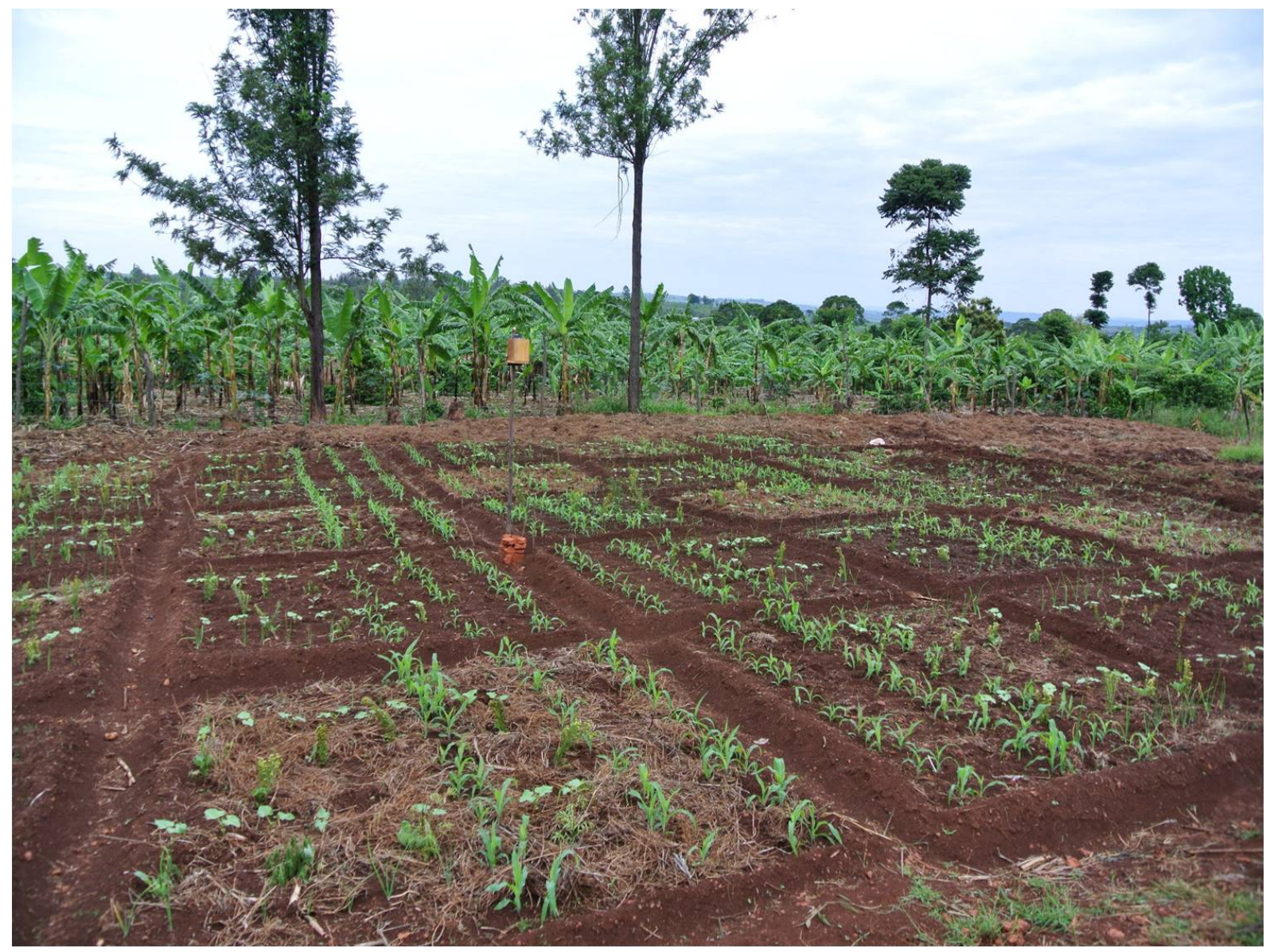

Fig. S3. The experimental site - 22 days after initiating the experiment with sowing of maize. The photograph was taken by A. Krause on March 26th, 2014. 


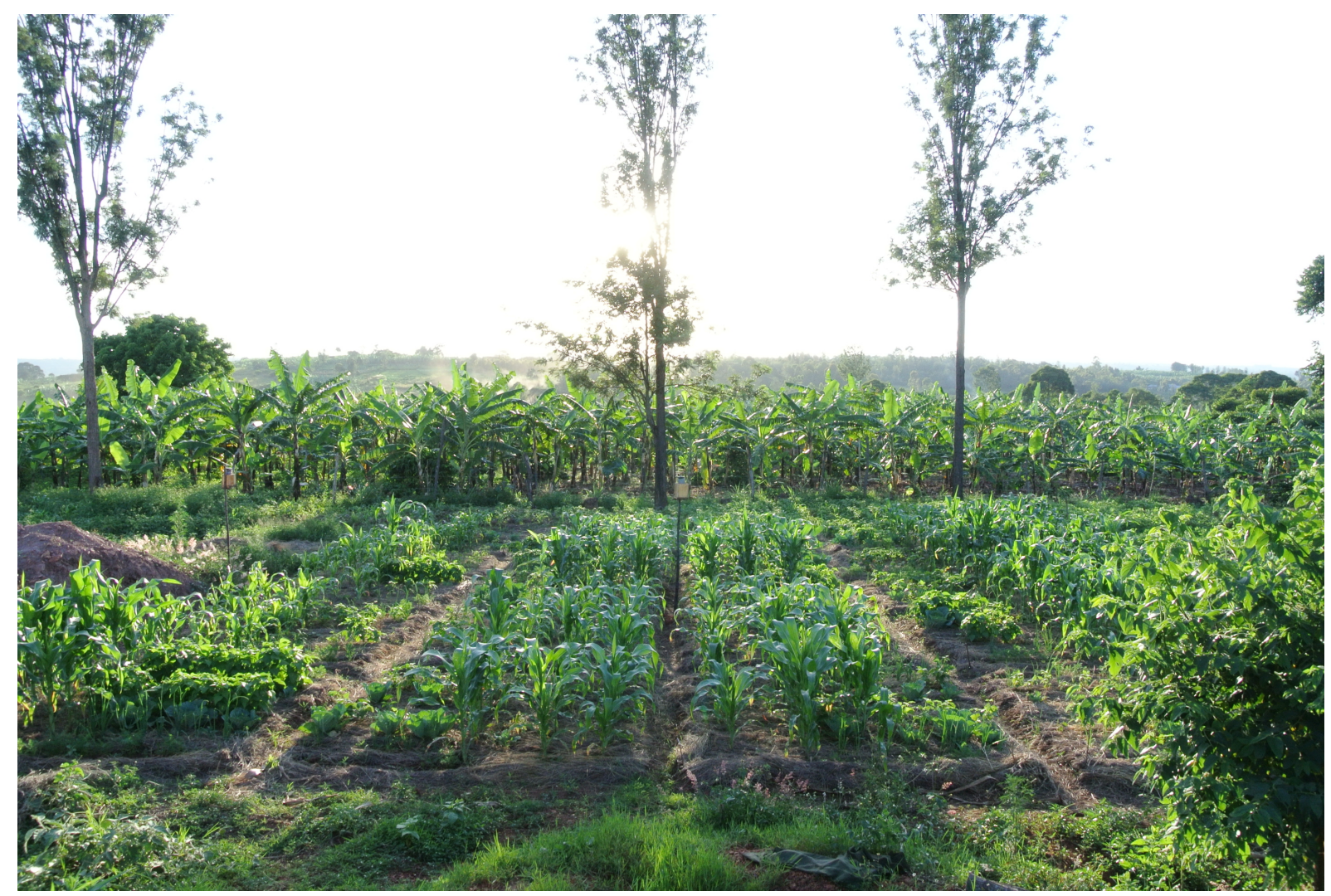

Fig. S4. The experimental site - 30 days after initiating the experiment with sowing of maize. The photograph was taken by A. Krause on May 2nd, 2014. 

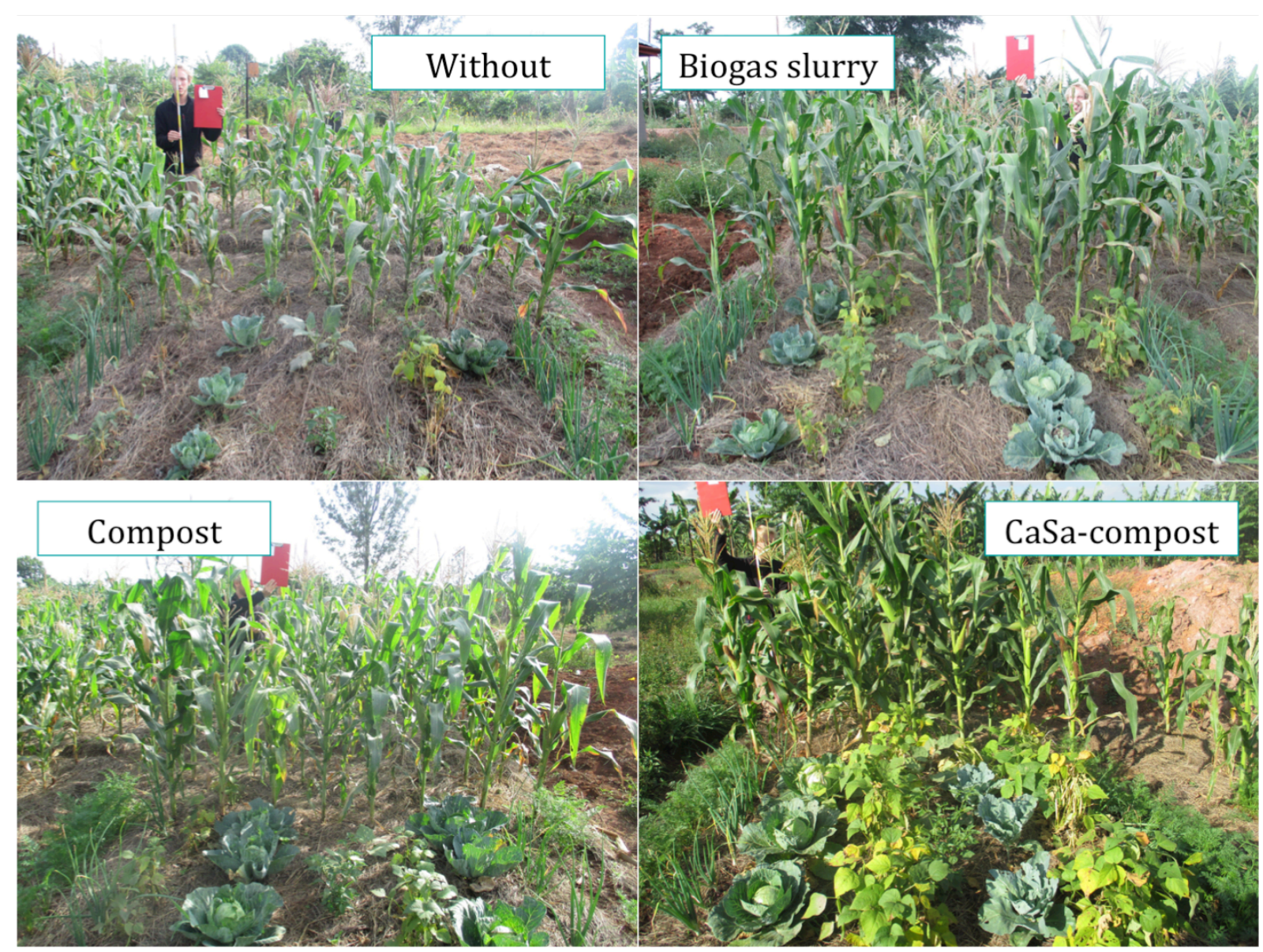

Fig. S5. Progress of the experiment - 60 days after initiating the experiment with sowing of maize: an untreated plot (without) compared to plots amended with biogas slurry, compost and CaSa-compost. These photographs were taken by A. Krause on June 2nd, 2014. 


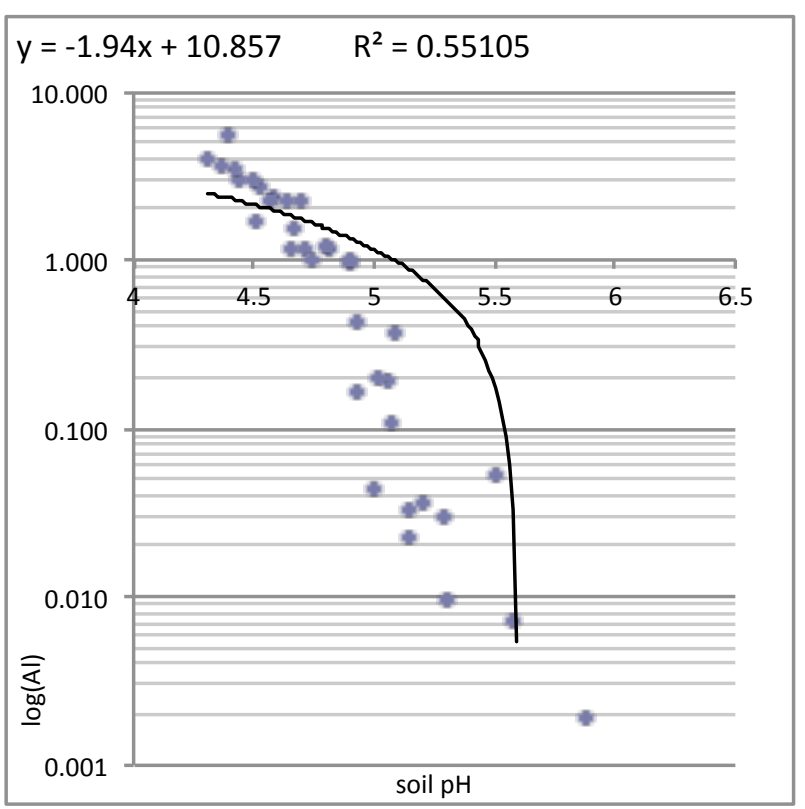

Fig. S6. Regression analysis: concentration of exchangeable $\mathrm{Al}$ against the $\mathrm{pH}$ for discussion in Sect. 3.5. 


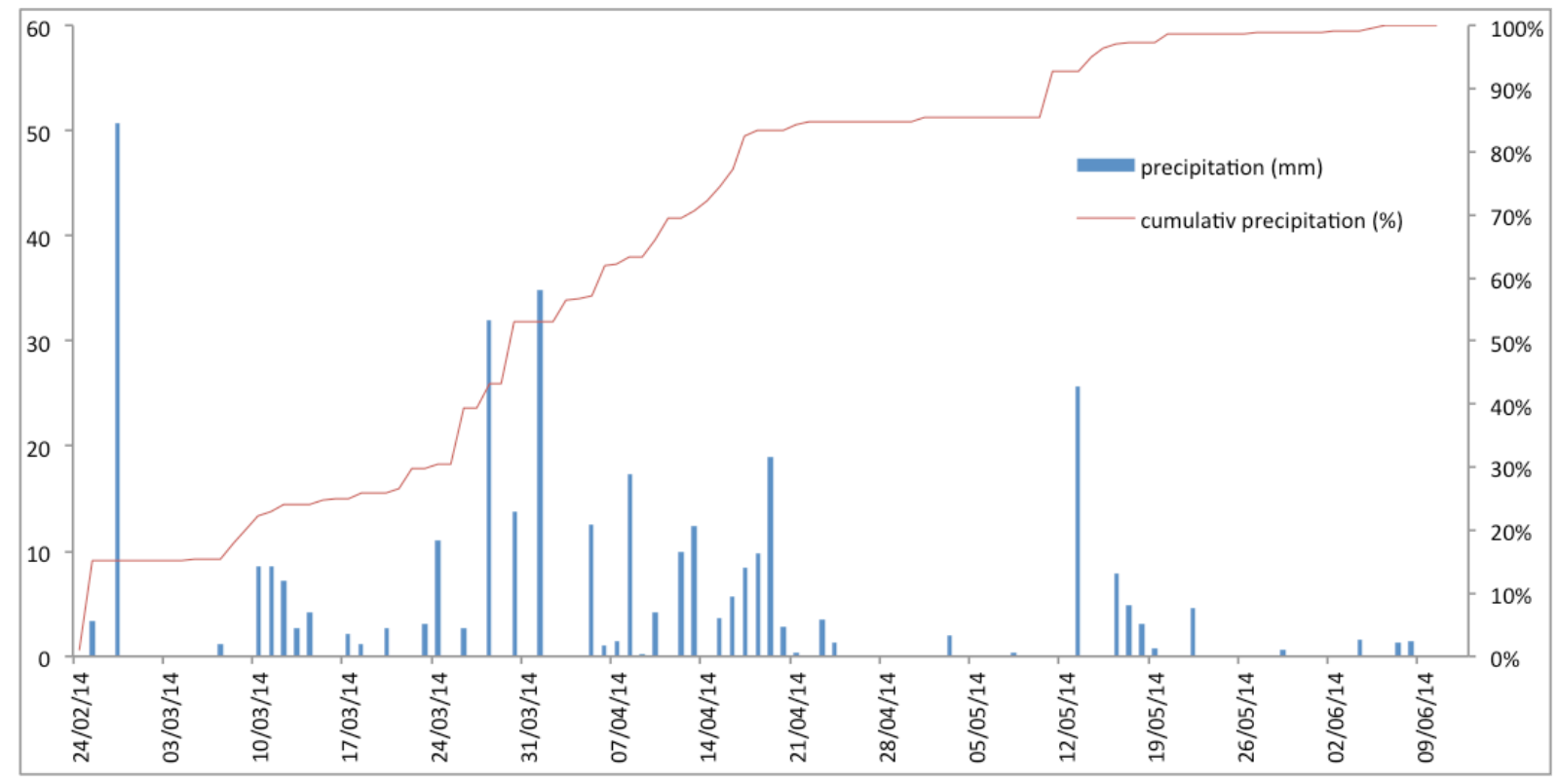

Fig. S7. Daily precipitation in $\mathrm{mm}$ (right-hand ordinate) and cumulative precipitation in \% (left-hand ordinate) during the course of the experiment from February to June 2014. 


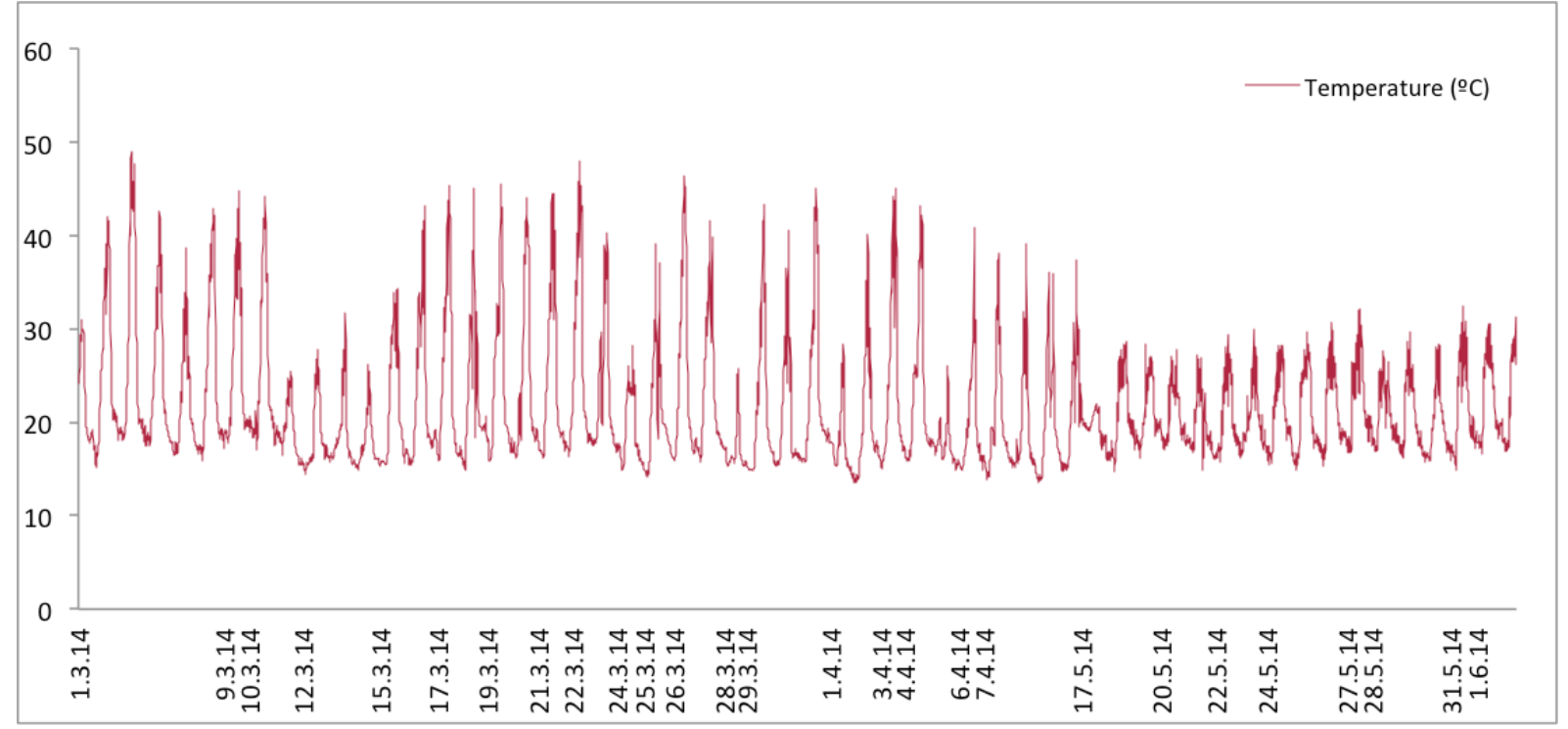

Fig. S8. Daily temperatures in ${ }^{\circ} \mathrm{C}$ during the course of the experiment from March to June 2014. 


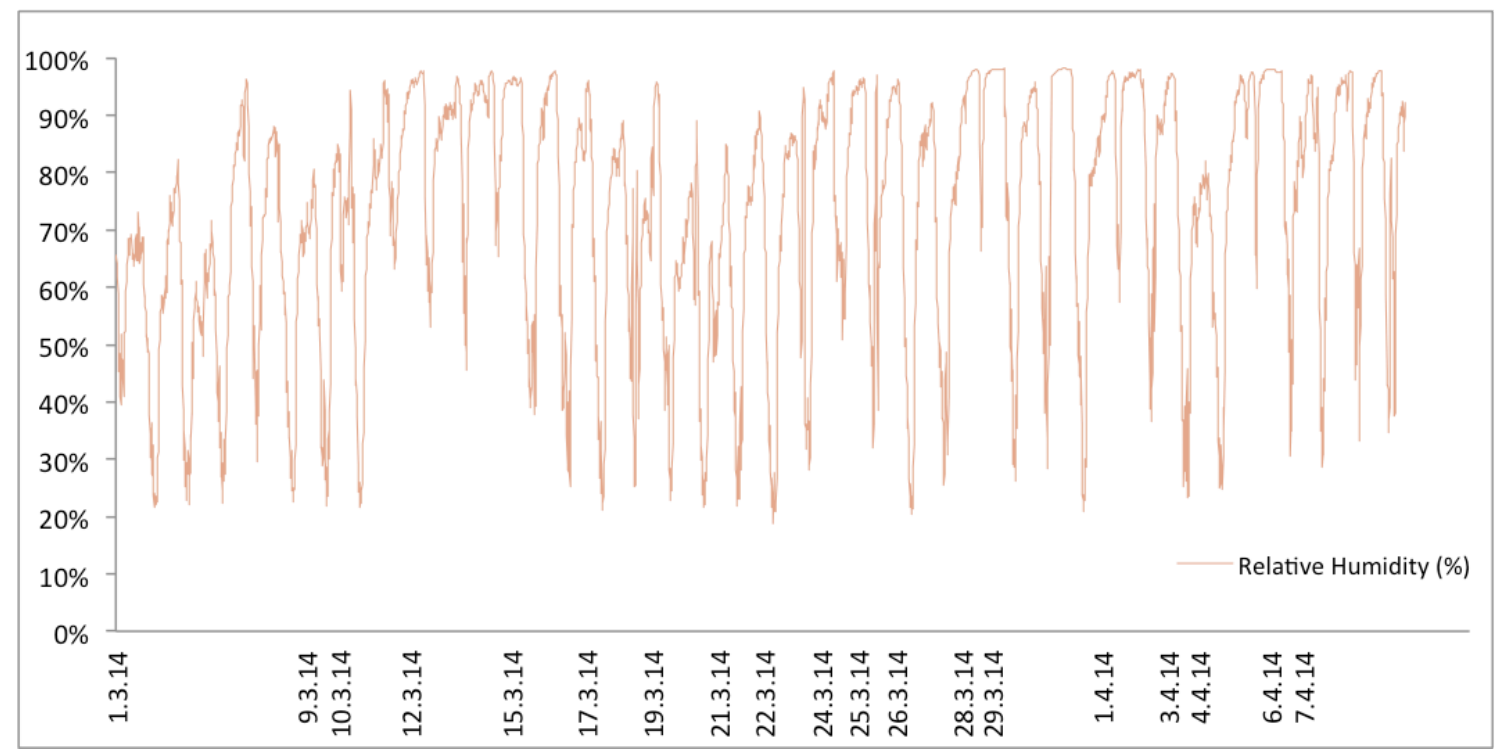

Fig. S9. Daily humidity in \% during the course of the experiment from March to May 2014; in June it was not measured due to technical problems with the device. 